\title{
On the Threshold: The Story of School Security Guards in Israel
}

\author{
Raz Shpeizer \\ Kaye Academic College of Education, \\ Azri'el Nitsani St 6, \\ Be'er Sheva, 8414201, Israel
}

DOI: https://doi.org/10.36941/mjss-2021-0oo2

\begin{abstract}
The global spread of neoliberalism has brought with it an increase in practices of outsourcing and subcontracting, and, consequently, the flourishing of private security services which rely on them. In Israel, these trends, combined with the unique security climate, have encouraged the development of a distinct subsector of private security in the form of school security. The rise of private security services has generated research interest. Most studies, however, focus on socio-economical aspects rather than on security guards' personal perspectives. This tendency is even more pronounced regarding school security guards and, to date, no studies have been carried out in Israel examining their viewpoint. This study aimed to address this lacuna by bringing in school security guards' voice in order to learn from and about them. The study's approach was qualitative, and the main tool was semi-structured interviews, accompanied by observations and document analysis. The study's findings reveal that the world of Israeli school security guards is informed by one fundamental quality. This quality is liminality, and it colors their experiences, perceptions, and professional relations. Israeli school security guards are always on the threshold: between belonging and not-belonging to their workplace; between commitment to and alienation from their work; between being needed yet disrespected. The paper suggests that this liminality is connected to the global socio-economical changes, and furthermore, it expresses a central aspect of Israeli society, which swings between two incompatible ethe: the security ethos and the neoliberal ethos.
\end{abstract}

Keywords: Private security; School security guards; Neoliberalism; Liminality; Israel

\section{Introduction}

In May 1974, three members of the Democratic Front for the Liberation of Palestine (DFLP) entered Israel from Lebanon and occupied the Netiv Meir school in the city of Ma'alot. At the time, 102 students and ten faculty members from a high school in the city of Safed were staying at that school during a field trip. The DFLP took 85 of them hostage. After a brief negotiation, a commando unit of the Israeli army entered the school, but the rescue operation did not go as planned; 22 students and three teachers were killed by the DFLP members.

This event, often referred to as the "Ma'alot massacre", had far-reaching shock waves and set off a chain of reactions, including recognition of the state's need and obligation to protect people at educational institutions. By September 1974, the Israeli government enacted security regulations for educational institutions. They set guidelines for security to be carried out by volunteer parents or, in 
emergencies, by faculty members (Knesset Emergency Regulations, 1974). Security was to be carried out selectively, not in all educational institutions. In 1992, the government policy was changed. The new policy stipulated that from that time, security in educational institutions would be transferred to private guard companies. In 1995, it was decided that security would be implemented at all Jewish educational institutions with 100 or more students (Knesset Education, Culture and Sports Committee, 2002).

These historical events are embedded in the security and political context of the Israeli state and society. At the same time, the enacted policies reflect global political-economic trends towards indirect employment, i.e., "employment through private services contractors and employment agencies" (Nissim \& De Vries, 2014, p. 436), and large-scale privatization of public services (Briken, 2011), specifically the growth of private security services (Van Steden \& Nalla, 2010; Van Steden \& Sarre, 2010). In Israel and internationally, indirect employment is now the primary mode of employment for security guards, including those working in educational institutions (Nissim \& De Vries, 2014).

Security in educational institutions has distinctive structural characteristics, given the population to be protected, and the roles, activities, and goals of these institutions. This creates an interface between two realms, with implications for both. The distinctiveness of the Israeli context is expressed both by the scope of the school security system and the use of armed security guards, which is not common in other countries.

The rise of private security services has led to expanded research on the subject, most of which addresses social and economic issues. Only a handful of studies explore the personal world of private security guards (Manzo, 2011), especially that of school guards. In Israel, research generally focuses on the problematic employment conditions of guards. No previous studies have examined their point of view. Thus, the population of school security guards in Israel is a disadvantaged population, in terms of employment conditions and in the dearth of research dedicated to them. The current research aims to bridge this gap. The main research goals are to document and explore the voices of school security guards in Israel regarding their world, experiences, and perceptions, taking into account the distinctive context in which they live and work.

\section{Literature Review}

\subsection{Neoliberalism, Private Guarding and Security}

The expansion of the private security sector around the world is linked to the spread of neoliberalism (Briken, 2011; Meško et al., 2005; Noronha et al., 2020). While there is debate about the exact definition of neoliberalism (e.g., Birch \& Springer, 2019; Thorsen \& Lie, 2007), there is agreement that one of its basic characteristics is the assumption that protecting economic freedom is the main tool for advancing peoples' well-being, and only for its sake is the state entitled and obliged to intervene in the functions of the market or society (Harvey, 2005). This implies, at least ostensibly, that the state should minimize its economic and social involvement. Neoliberalism has guided the course of action adopted by many countries and the global economy overall, such as deregulation of market activity, cuts in state expenditure overall and for social services in particular, and the privatization of public enterprises, services, and assets (Brenner \& Theodore, 2002; Mandelkern, 2015).

The growth of private security services can be seen as a result of the privatization of public services previously provided by the state. However, some researchers (e.g., Brown, 2006) argue that this growth, like that of other private services (private schools, private medicine, etc.) reflects the neoliberal tendency to convert political and public problems into market problems and to offer market solutions. Thus, in the neoliberal era, defense and security have become products, and the scope of the private security sector correspondingly expands (Meško et al., 2005). This process is especially prominent in Israel, where there is a core ethos of security, according to which the state and its citizens are in constant danger and their safety must be ensured (Lissak, 2001; Peri, 2006; this 
point will be expanded later).

\subsection{Status of Private Security Guards, Internationally and in Israel}

Despite increased demand for their services, the social and economic status of private security guards around the world is dismal. They are portrayed in a poor light by academics, in popular culture, and by their supervisors, who often criticize their skills, efficiency, and integrity (Dempsey, 20o8; Manzo, 2011; Noronha et al., 2020; Prenzler, 2004; Zender, 2006). They have poor employment conditions, such as low salaries, temporariness, little bargaining power, and weak unions (Briken, 2011; Nalla \& Cobbina, 2017; Shukla, 2017). Many feel unappreciated and insecure.

The penetration of neoliberalism into Israel (Kaplan, 2010; Mandelkern, 2015), alongside the deterioration of domestic security, especially since the outbreak of the first intifada in 1987, has created fertile ground for the growth of private security services (Handels, 2004). Private security has expanded into areas that were once the preserve of the public. Further, contractor companies have largely taken over transactions in the field of security, transforming it into a triadic field, where guards are seldom directly employed by the institution for which they are responsible (Wininger \& Teschner, 2013).

In recent years, awareness of the precarious employment status of security guards in Israel has increased. Certain improvements have been made in the legislation, supervision, and enforcement of their rights (Wininger \& Teschner, 2013). However, these changes do not address the basic structure of contractual employment. Additionally, the regulations are difficult to enforce, and security companies often fail to respect the rights of their employees (Davidov, 2010; Levy, 2005; Wininger \& Teschner, 2013).

\subsection{School Security Guards in Israel}

The status of school security guards in Israel is similar to that of other types of security guards, and in some aspects is even more vulnerable, mainly because they are subject to more criticism than other types of security guards (as will discussed in greater detail later). ${ }^{1}$ In the hierarchy of the world of private security, personal bodyguards are at the top, and at the bottom are: "jobs where you stand daily in front of a discount store [...] 'there you are really lost,"' (Briken, 2011, p. 137; see also Noronha et al., 2020). Prima facie, school security guards, who spend most of their work days at the school gate, whose professional demands are minimal, and whose working conditions are among the worst, are near the bottom of this hierarchy.

Davidov (2010) argues that the justification for employment of contract workers in schools is based on the distinction between the "seed" and the "shell"; between activity that is ostensibly the core purpose of the school (teaching), and activities perceived as peripheral. He notes that, in addition to damaging economic and employment conditions, this distinction diminishes "peripheral" workers' sense of belonging, reduces motivation, and generally marginalizes these workers. While this applies not only to security guards or school service staff, but to most people indirectly employed, it should be noticed that there are differences between being a guard and, for example, janitorial work, and that school is a distinct framework with highly sensitive features, stemming from the institution's population and its goals. In this respect, the lack of qualitative research on school security guards is even more striking.

\footnotetext{
${ }^{1}$ It should also be noted that until 2018 school security guards in Israel were subject to the vacation schedule set by the Ministry of Education and were not paid for these compulsory leave days (Wininger \& Teschner, 2013). While these regulations were changed in 2018, there are still many guards who complain about not being paid for school vacations or summers break (see, for example, Zvi Cohen, 2018. This point will emerge later, in the findings section).
} 


\subsection{Perspectives of Private Security Guards Internationally and in Israel}

Studies examining the experiences and perceptions of private security guards find that most did not plan to be guards and do not view their jobs as a career, but as a temporary stage on the path towards better employment (Briken, 2011; Handels, 2004). Private security guards emphasize the boredom and stress of their work, and often feel under-appreciated by the public (Briken 2011; Meško et al., 2005; Nalla \& Cobbina, 2017; Noronha et al., 2020).

The USA and Israel are among the few countries with organized, comprehensive security in schools. However, there are substantial differences between the two security realms. First, the primary goal of school security in the USA is not to protect against external attacks, but to prevent violence within schools (James \& McCallion, 2013). Second, unlike in Israel, most security guards in the USA are police officers who work on or off duty (Layton \& Shaler, 2019; Maskaly et al., 2011). Therefore, studies conducted in schools in the USA do not accurately portray the world of school security in Israel, but they do have some relevance regarding the work context. School guards in the USA perceive their role as providing security for the school, students, and staff (Caine et al., 1998). They report feeling stress and burnout resulting from their sense of responsibility and fear of injury to students (Ely, 2010). Many complain of inadequate cooperation, recognition, and understanding from parents, students, and teachers; they express a desire for better communication with these groups (Ali et al., 2013; Caine et al., 1998; Ely, 2010).

\subsection{Liminality}

As will become clear, the concept of liminality is critical to understanding the world of school security guards in Israel. Thus, two points should be emphasized relating to the use of this term in the current study. First, the concept arose inductively from the collected data; it was not deductively imposed. Only after the concept emerged from the data analysis was it applied theoretically to the study. Second, the term's meaning in the current study deviates from the orthodox meaning, as will be clarified, in order to adapt it to the empirical experiences of the participants.

The concept of liminality originated in anthropological research. Van Gennep (1960) first used the term to describe a ceremonial transitional phase between one social status and another. Subsequently, the term was used in Turner's $(1967,1969)$ classic study of the Ndembu tribe in Zambia, to describe the transition from childhood to adulthood. Ndembu boys pass through a stage during which they are cut off from their surroundings and previous roles. They do not yet belong to the adult world but are no longer part of the world of children. This liminal stage is characterized subjectively by feelings of uncertainty, confusion, and loss, as well as objectively by the absence of rights and power, and lack of defined social status and roles. It ends upon their entry into the adult world and the granting of a new status, role, and identity; stability and clear boundaries again characterize their lives.

In Turner's later work (1988) and that of his successors (e.g., Szakolczai, 200o), the concept of liminality is enriched and extended beyond rituals observed in traditional societies. Application of this concept has expanded beyond anthropology to all human sciences (Thomassen, 2009). The concept of liminality in use today is flexible, emerging from Turner's (1967) definition of it as any situation or object that lies "betwixt and between"; an intermediate stage or position between one category and another. This concept can be applied to individuals or groups, and to various periods of time. Some even apply it to non-human objects (such as international borders, see Thomassen, 2009). However, it is most commonly applied to human experiences with distinct beginnings and ends: entry into and exit from the state of liminality.

The concept of liminality has been applied to research on labor and organizational relations (Beech, 2011; Tagliaventi, 2020), such as the situation of employees undergoing changes in their working relationships (Spyridakis 2013), and those in temporary or indirect employment (Borg \& Söderlund, 2014; Garsten, 1999; Underthun \& Jordhus-Lier, 2018). The concept is often associated 
with negative workplace phenomena, such as stress, lack of sense of belonging, and job insecurity (Borg \& Söderlund, 2014; Daniel \& Ellis-Chadwick, 2016; Winkler \& Mahmood, 2015).

There is a close and even causal relationship between the state of liminality and the state of precarity. In the last few decades, there has been a significant increase in the number of people in situations of "...employment that is uncertain, unpredictable, and risky from the point of view of the worker" (Kalleberg, 2009, p. 2). This increase is explained by the spread of neoliberalism and globalization, which intensifies competition and freedom for employers, while reducing protection and security for workers (Kalleberg, 2009; Nissim \& De Vries, 2014). Clearly, employees are more likely to experience liminal situations due to unprotected working conditions, non-voluntary mobility, and lack of a stable workplace.

\section{Research Objectives and Questions}

The objectives of the current study are:

(1) To explore the world, experiences, and perceptions of security guards working in the distinctive context of schools in Israel.

(2) To provide a platform for the voices of the disempowered population of school security guards in Israel, shedding light on the conditions of their existence.

Two main questions guided the study:

(a) What are the characteristics of the experiences of school security guards in Israel?

(b) How do Israeli school security guards perceive themselves and their work?

\section{Methodology}

A basic (generic) qualitative approach was deemed most appropriate for the research objectives. This approach is essentially constructivist, that is, it presupposes that meaning is a human construct and thus the researcher is interested in "understanding how participants make meaning of a situation [...and] seeks to discover and understand a phenomenon, a process, the perspectives and worldviews of the people involved, or a combination of these," (Merriam, 2002, p. 6). By definition, the generic method is based on a small number of assumptions and action patterns. It is flexible, drawing from formal methodologies (such as phenomenology or grounded theory) without committing "full allegiance" to any of them (Kahlke, 2014, p. 39). This flexibility makes it suitable for the present study, which seeks an unrestricted perspective on its subject.

The main research tool is semi-structured in-depth interviews. In addition, I examined and analyzed documents from sources including: the Israel Ministry of Education, police reports, transcripts of Knesset (parliament) debates, government policy decisions, and news media. I conducted several limited on-site observations of school security guards at work.

\subsection{Study Participants}

Participants were selected using the purposive sampling technique (see, e.g., Palys, 2008). To learn about people with a common background experience, some homogeneity is required (Patton, 2002). This is one reason the study population does not include security guards in kindergartens and guards in Arab-sector educational institutions. ${ }^{2}$ At the same time, to explore a variety of perspectives, the selected study population is diverse in terms of gender, age, ethnicity, residential region within Israel, and type of school at which they are employed. Twenty-five participants were interviewed: ten

\footnotetext{
${ }^{2}$ There are two additional reasons for the exclusion of security guards at Arab educational institutions in this study. First, only some of these institutions are guarded. Second, the guards are mostly unarmed. Thus, the security norms and the social context at Arab educational institutions differ enough from those in Jewish institutions that the guards' experiences need to be examined separately.
} 
women and fifteen men.

\subsection{The Interviews}

Interviews were coordinated with the intention of finding a place that was convenient for the participants and with as little disruption as possible. I conducted three pilot interviews to focus the research questions, build an interview guide, and locate potential participants. The average interview time was approximately 100 minutes. Before commencing the interviews, participants were informed about the study's aim, and reassured about confidentiality and anonymity. They were also told that participation in the study was voluntary, and that they are free to cancel their participation at any time. All participants were asked to give verbal consent, which was recorded.

\subsection{Data Analysis}

The data analysis applied was based on the constant comparative method, starting with open coding, followed by axial and selective coding (Merriam \& Tisdell, 2015; Strauss \& Corbin, 1998). To ensure the quality of research, I followed Lincoln and Guba's (1985) approach based on the concept of trustworthiness rather than validity. They recommend various means to increase trustworthiness, including deep and consistent research, triangulation, peer review, thick description, and keeping a research log.

\subsection{Limitation of the Study}

Due to the limited scope of the data collection through observation as well as to the fact that no quantitative methods were used, the methods triangulation (e.g., Patton, 1999), which is based on comparing different methods of data collection, was somewhat limited. Due to confidentiality concerns and financial limitations, no further analysis of the data by other researchers (analyst triangulation, see Merriam \& Tisdell, 2015; Patton, 1999) was possible. However, at different stages of the study, portions of the findings were presented to other researchers, and their critiques were used to refine and elaborate upon the findings.

\section{Findings}

Data analysis reveals five themes characterizing the world of school security guards in Israel:
(a) job definition
(b) responsibility
(c) professional disrespect
(d) temporariness
(e) loneliness

One core, overarching theme connects these five themes, indicating the infrastructure of experience and perceptions of school security guards. This theme is liminality, which exemplifies the life of school security guards in terms of their instability, insecurity, and lack of sense of belonging. In the following sections, I examine how liminality is expressed in each of the five specific themes and in the relationships between them, collectively describing the world of the study participants.

\subsection{Job Definition}

The liminality of school security guards in Israel begins with the definition of their roles. This includes three aspects: physical location, mental location, and professional location. The Director General of Israel's Ministry of Education (2012a) states that "security in educational institutions is based on the presence of a static security guard/watchman at the school gate" (sec. 2.2.1). The guard 
must oversee school security "and address two major threats: (a) hostile terrorist activity and (b) threats to public security" (The Director General of Israel's Ministry of Education, 2012a, sec. 2.2.1).

The interviews and observations confirm that the school security guards spend most of their day at the school gate: "For fifteen minutes, tops, I can be away from the gate, then I must go back [...] I use the bathroom, eat, drink, do a quick scan, walk around for a minute, then return." "After everyone comes in, I close the gate, and I pretty much stay there." They see a connection between the need to stay at the gate and their responsibility to protect the school from harm originating outside the school. "If you're inside or not in the area, you're not aware of what's going on. Let's say I go inside for a long time, and someone jumps out from here [...].” Thus, in accordance with the official definition of their job, school security guards are literally on the threshold between the school and the outside world. At the same time, they perceive their role (mental location) as a barrier between the outside and inside, protecting the latter from the former.

The official definition, quoted above, includes a dual reference: security guard/watchman. The formal distinction, according to the Israel Police (1998), between a watchman and a security guard is that only security guards are armed on the job. Currently, most school guards are defined as "watchmen", and all new guards are hired under this job definition (Wininger \& Teschner, 2013). However, since armed security is required at Jewish schools (Israel Ministry of Education, 2012b, sec. 1.1) their training, duties, and powers are those of security guards (Wininger \& Teschner, 2013). This is how most of them define their own role as well. "I am a security guard. A watchman is unarmed, a security guard is armed."

There may be economic reasons for the preference of the job definition "watchman", since Israel's Ministry of Defense finances $64 \%$ of the costs for watchmen and $100 \%$ of the costs for security guards (Municipality of Haifa, 2018; Wininger \& Teschner, 2013). In any case, it causes a sense of professional liminality among school security guards, because their place in the security hierarchy (Briken, 2011) remains unclear. They are on the conceptual and practical threshold between a watchman - who hardly requires any special skills or training, and whose professional position is at the bottom of the hierarchy, and a security guard - whose required skills and perceived level of professionalism are higher. This obfuscation indicates an additional layer of liminality related to the value that society and the guards themselves attribute to their work, as will become clear in the sections on the following two themes and the relationship between them.

\subsection{Responsibility}

Similar to school security guards in the USA, the study's participants perceive the primary significance of their role as the responsibility to protect, especially children and youth. "In one word? It's a matter of responsibility." "It's a responsibility for 400 children. I'm not talking about staff; I'm talking about children. To go home every day thankful that nothing happened, no one was hurt."

Some note the responsibility of being armed. "Weapons are a responsibility. You work with children and have responsibility for children, it is not an easy responsibility." They feel they must protect students from possible attacks: "Especially in Israel, which is a risky place, terror attacks, stuff like that."

The need for constant vigilance is derived from their perception of responsibility and potential danger. Again, like guards in the USA (Ely, 2010), Israeli school security guards express tension that accompany this responsibility: "It's hard to always be alert. You mustn't blink for a moment, always look around, always be on guard." "If, heaven forbid, something happens, and you aren't alert to the environment ... it's bad."

At the same time, they derive a certain sense of self-worth and value from their responsibility. "This is completely different, you know, more difficult than other places. You're in charge of school security, safety of children, teachers, you understand?" 


\subsection{Professional Disrespect}

However, as against the value that arises from their sense of responsibility, the guards are aware of disrespectful attitudes towards their role, professional ability, status, and of low value attributed to their work. This deepens their sense of liminality, of being caught between professionalism and unprofessionalism, importance and unimportance, and hinder the formation of a stable professional identity.

As discussed in the literature review, this problem is most obvious in their terms of employment. All the participants voice complaints about their working conditions, such as low wages: "The salary is terrible"; quality of their equipment: "You can hardly call our uniforms 'clothes"; the school vacation schedule: "This is the problem with contract workers, they don't get paid for holidays, uh, especially school security guards,"; and not receiving the conditions they deserve from the contracting security companies: "There are some companies, like [name of company], who don't care about you." "It's not right. You shouldn't have to ... come to your supervisor and prove when you worked, when you didn't, to fight with them."

The guards make special note of the security booth; the structure at the entrance to the school where they spend most of their time, store their equipment, and sometimes keep personal items. Designed to protect them from the weather, many booths do not provide a minimal level of comfort. Some have no electricity and look like shacks on the verge of collapse. One participant, Yossi, says: "The booth is an oven. Some people sit in the booth, but I don't understand how they do it." Some municipalities have taken steps to improve this situation, but often only after guards struggled for changes. Another participant, Michal, tells this story:

Last year, the roof in my booth was leaking [...] I suffered terribly until they finally fixed it. Over and over I asked and begged and pleaded. I told them I was getting so wet inside I may as well be outside. Finally, they stuck up a piece of wood so no rain would come in. They told me this is temporary, in the summer there will be renovation. I said fine [...] It's hard to have to beg for a little heating or cooling. Everyone tells me to ask someone else. In the end, I went to the principal and told her, I don't have a heater, I don't have a fan, I have nothing. It's too hot or too cold. You have to give me something. So, she tells me, you know what? I'm going to fix up something for you. That was on Friday, and on Sunday she brought me a fan. I also had to chase after the staff, until they gave me a heater not worth a shekel, because it only half works. One of the teachers brought it, not the management, not the custodian [...] I don't even care anymore, I'm leaving here anyway.

In accordance with the findings of studies from other countries (Briken, 2011; Dempsey, 2008; Manzo, 2006; Noronha et al., 2020; Prenzler, 2004), Israeli school security guards also experience societal disrespect. First, most of the participants feel the Israeli public's general assessment of security guards is low.

Society doesn't see the guards. We're nobodies to them. You're just a security guard, just someone poking your hand in their bags, into their life [...] They're always putting you down, humiliating you, saying, "You're nothing but a guard."

Second, the guards complain about the failure to recognize their authority by those at the school, especially the parents. "Something we have to deal with is, uh, arguments with the parents." "It was a difficult at first, with the parents, because I have to write down whoever comes in, and they would say 'No, I'm a mother', or they don't want to give me their details." "It's Israeli culture, and there are some [parents] who are rude, like 'I'll park here because I feel like it,' or 'I don't have time for you to check my ID."

Third, there is criticism of school security guards in the media. Alongside publications on the problems of their working conditions, some cast doubt on their professionalism and express concern for students' safety (Blumenthal, 2016; Devorat, 2002; Lansky, 2012; Schlesinger, 2013).

Finally, their employers do not appreciate their professional skills. Guards are instructed to call 
for assistance in every event, and to be cautious in exercising their de jure authority. Thus, participant Ido recounts an incident of someone jumping over the school fence: "I was supposed to hold him, but I didn't want to grab him because he hadn't done anything [...] if I touch him, he can even sue me." A senior security official exemplified the point, when during an interview he rhetorically asked the reporter, "Is a school guard who makes NIS 23.70 an hour [about \$6.50] and brings home a monthly salary of NIS 3,500 [about \$10oo] going to sacrifice his life for the homeland? It's a joke." (Schlesinger, 2013, para. 30).

Thus, participant Eyal, when asked towards the end of the interview about his final thoughts on school security guards' situation, expresses the liminal oscillation between responsibility and professional disrespect:

But for sure, our job means something. We have responsibility for the children [but] I hope they will change our wage, our working conditions, which is important, you know, because then being a security guard will also be respected job.

\subsection{Temporariness}

All participants, including veterans of five or more years in the field, emphasize the transient dimension of their work. They address two main aspects. First, most express a desire to find another job, because of aspirations for greater self-realization, the difficult working conditions, or a combination of these. "I connect with kids. I'm thinking to study something, maybe to become a kindergarten teacher or assistant; some job with children." "This is not a life-long job, I'm telling you, it's not a job at all. If I want to have a family, I need to find a more reasonable job." "I want to find a job that suits my education. I get nothing from working in security [...] They sapped all my strength."

Second, in line with previous research (e.g., Wininger \& Taschner, 2013), participants experience non-voluntary mobility between schools or security companies. This is a result of the market structure, in which companies compete in tenders for security services contracts. One participant asks: "Why are there tenders, and the company which offers the lowest price, wins?" Some note that if the company employing them loses the tender, they can request to transfer to the company that receives it, and thus continue working at the same school. However, even when this is possible, they have to "Fill out forms, do all kinds of renewals," and re-develop their working relationships. In either case, most of them occasionally move between companies or schools, voluntarily or involuntarily. "If the security company suddenly loses the tender at the school, God help us."

Therefore, temporariness, which is a characteristic of unstable working conditions in the neoliberal era (Kalleberg, 2009), places Israeli school guards in a constant state of liminality, caught between their current workplace and the next. Like their peers in Germany (Briken, 2011), for example, they keep hoping to eventually find a job that is more stable, more suitable, more profitable, and less vulnerable. "For now, I'm staying here. I have no choice. Until I find myself, and I have enough money. Being a security guard is not a career."

\subsection{Loneliness}

Loneliness, in its simple sense, is the feeling of being alone, with nobody to be with. The loneliness of school security guards begins with the physical aspect of their work: they spend most of the day alone at the school gate. All the participants complain about their loneliness, and often its companion phenomena of boredom and routine. "It has to do with the work itself, because it's a lot of hours to be alone $[\ldots]$ and mentally, it means being with yourself a lot."

It's a boring job because you have nothing to occupy you all day. There are days that no one goes in or out. You just sit here all day. A job that is exhausting from not doing anything, as they say.

However, the loneliness of the school security guards has deeper roots in their sense of non- 
belonging. Like the boys in Turner's $(1967,1969)$ research, who are no longer part of the group of children, but are not yet part of the group of adults, and thus are cut off from any stable social group, school security guards do not feel they are part of the organization that employs them (the contractor companies), or part of the schools in which they work. This already was indicated in the complaints about lack of trust between them and their employers and Michal's story of her booth's condition, and reiterated in reports about their need to take care of all their own needs. "Here, you have to fight with people to get a shade net, for electricity," says Kfir; "For transportation," adds Erez, and Ido expresses the sense of loneliness in a nutshell: "In security work, you have nothing, you have no support for anything."

Yet guards' relations with the schools are not identical to their relations with the employing security companies. They are at the school, even if just at the gate, for a large part of every day, and interact with the school population. Don't they feel part of the school community? Most participants report involvement in school activities that goes beyond the definition of their role and which suggests an aspiration to belong, and perhaps to boost their sense of dignity (Noronha et al., 2020). Some help the school custodian: "If he needs help with something, lifting chairs or heavy tables, I help him." Nearly all say they help parents with matters concerning their children: "sometimes they [the parents] ask me to bring their kid outside or wait with him until they arrive." "The parents trust me ... Even if it's not my job, I do it." Most speak in positive terms about their relations with the school staff, which seem to affect their sense of belonging and enable their proper functioning (see also Ali et al., 2013; Caine et al., 1998; Ely, 2010). "I can go to the teachers' room, make coffee, use the sugar, glasses, drink it there, no one tells me not to, you understand? No one. I feel like we are a family." "It's good that there is a connection with the teachers, because if there isn't, the school would fall apart."

Further, the longer guards work in a single school, the stronger their sense of belonging and familiarity with the staff, students and parents: "At first, it was hard. The children, umm, you know, want to check out who you are." "In the beginning it was difficult because I didn't really know them [the students, the parents and the staff] but now it's much easier."

Nonetheless, not a single participant feels fully affiliated with the school system. It is clear that the sense of temporariness and the always-present possibility of ending their work there, has an impact. But additionally, most explain that even if their relationship with the staff goes beyond the norm, this results from the initiative of individual staff members, rather than a systemic approach:

The management doesn't bother to invite me [to school events]. It's the teachers who tell me, "Come, you are invited." But the teachers are not the management. The management should come to me and say, "You are one of us, please come."

Moreover, in accordance with Davidov's (2010) distinction between core and peripheral workers, the participants draw an ostensibly clear line between themselves and the teachers in terms of the relationship with students, claiming that only teachers should educate, interact, and generally connect with students. "Education is for the teachers. It has nothing to do with me." "There are fights between the kids here, but that's not my job. The teachers deal with these things." "I get along with the students everywhere because I, I don't connect with them, don't communicate with them." "I tell them [the students]: when I work, I don't like anyone sitting with me.” Indeed, seemingly security guards and their employers alike interpret the law stating that they are not allowed to exercise any authority in relation to the students (Israeli Authority for Maintaining Public Safety Law, 2005) as a prohibition against any contact between them and the students. "This is well known, and our supervisors also tell us, not to get too involved with the children."

However, alongside their repeated statements about the lack of deep relationships with students and the prohibition against developing them, many participants mention the happiness the children bring them, and their special connection with them. "It's best with the kids, like you're connecting with them." "The positive side is the children; their attitude, the love they give." Some 
enthusiastically recall gifts they received from students. In her booth, Michal keeps greeting cards the students made for her:

It was last year on Good Deeds Day. The whole class made me cards. Really beautiful. Each wrote what he felt. "Thank you so much for all your hard work and effort - from the redhead you see every Sunday at four o'clock" [...] "Thank you for greeting us each morning and for laughing with us - from [student's name] in 5 th grade."

Even the security guard quoted above as saying that he doesn't want students to sit with him at work, also says, "The relationship I have with the students is the most important." Similarly, a security guard who said he does not approach students because of concerns about parents' reactions, headed towards the school at the end of our interview. When I asked where he was going, he smiled and said he lent his soccer ball to a student and was going to get it back.

These contradictions in the school security guards' stories illustrate the gap between what they perceive as forbidden regarding their relations with students and the connections they want and sometimes realize; between their defined role and the natural emergence of human interactions in a shared space. At the bottom line, they express most clearly the guards' lonely position on the threshold, between being part of the school and being disconnected from it.

Sometimes I see myself as part of the school and sometimes I don't. It's like they say you are part of it, yet not part of it [and] you feel a sense of belonging and not belonging. You are told "you are one of us", but, in reality, you are not one of us.

\section{Discussion and Conclusion}

A wide-perspective examination of the current study's findings reveal that they are in accordance with previous studies (Garsten, 1999; Nissim \& De Vries, 2014; Spyridakis, 2013; Underthun \& JordhusLier, 2018), which found that a feeling of being on the threshold and a state of liminality characterize the unstable working conditions prevailing in the neoliberal era (Kalleberg, 2009). Furthermore, the findings indicate a possible connection between the structure of indirect employment and the experience of liminality; a connection that might appear probable, since, by definition of this form of work, employees are caught between the contracting company and the service-hiring company, and are thus unable to feel they belong to either, as frequently seen in the participants' comments. This point is important for the understanding of the neoliberal labor market, which is characterized, especially in Israel, by the large scale of indirect employment (Nissim \& De Vries, 2014).

Yet, further analysis of the findings reveals that the liminality that characterizes Israeli school security guards' experiences and perceptions of themselves and their work, has some unique aspects which intensify it and make it broader and deeper than what is commonly described in the research literature. First, the classic theoretical concept of liminality refers to socially-defined situations that have temporality embedded in them, and represent an intermediate stage between a pre-liminal state and a post-liminal state, which are relatively stable and safe (Turner 1967, 1969; Van Gennep, 1960). Israeli school security guards are not in this situation. Their liminal situation is ongoing, with no clear finish line. Although they strive to overcome this liminality and establish greater security, this aspiration is purely personal. Its realization depends on the individual, without the support of any social structure or organization.

Second, liminality is structured into their job description and hence their professional identity. Their job description fluctuates between that of a watchman, whose duties are passive supervision, with minimal training, located at the bottom of the security hierarchy, and that of an armed security guard, who requires greater professional knowledge and is higher in the hierarchy. This fluctuation is intensified by the contrast between their sense of responsibility about protecting students' lives, and the disrespect - experienced by many private security guards worldwide - they feel from the surrounding society: the general public, their professional supervisors, students' parents, which 
grants them little appreciation and often expresses doubts about their skills and abilities.

Third, the liminality of school security guards has a tangible physical aspect, since they are required to remain at the school gate, on the threshold between the school and the outside world, neither here nor there, "betwixt and between" (Turner, 1967). This position, rooted in the perceived need to protect the school from external threats, is projected onto their views of themselves as a barrier between the two worlds, further intensifying their sense of liminality.

Fourth, it could be argued that most watchmen and security guards work on the threshold between the place they are guarding and the threats to it, a claim which is easily understandable in Israel, where guards are an integral part of the landscape of daily life, commonly seen at the entrances to malls, supermarkets, and public institutions. Indeed, it is reasonable to infer that liminality is a characteristic feature of the guarding profession, which arises from the role definition of the guards as barriers between spheres and, as shown in the present study, has both physical and psychological aspects. When also considering the dimension of indirect employment, typical of the security industry in the neoliberal era (Briken, 2011; Meško et al., 2005; Noronha et al., 2020), a deep and multifaceted sense of liminality emerges. However, a school is not a mall or parking lot or train station. It is a place in which close personal relationships are formed, and where people are engaged in common activities with shared goals and with strong social and personal value. Faced with these deep and complex relationships, the lack of belonging and sense of liminality experienced by the school security guards are intensified. This explains why they repeatedly describe feelings of loneliness and isolation.

The guards, we saw, express a desire to belong, interacting with school staff and students in explicit and implicit ways, sometimes going beyond their official job description. But the law emphasizes school guards' lack of authority over the students. Social norms differentiate between the core and peripheral realms in the school (Davidov, 2010). The security companies require them to avoid contact with the students. The school administration discourages their integration into the system. All of these factors transmit the infeasibility and even inappropriateness of the guards' sense of belonging, thus deepening their sense of liminality, both practically and psychologically.

Nevertheless, school security guards inevitably have an impact on their surroundings and its tenants. Their liminality is also expressed through their role as agents who involuntarily bring the "real" world into the school and educational system in general. Through them, political, security, and economic issues infiltrate from the outside world. Many parents hope to at least partially shield their children from these issues in the seemingly-protected confines of the school. But a security guard with a gun (and the guards say the students inevitably ask about the gun) who sits or stands at the gate, who is part of the school but not really part of it, and who is occasionally replaced, suddenly and unexpectedly, is part of the reality of children educated in this social environment. For education is not limited to what educators intentionally transmit to students. It is additionally - perhaps primarily - a product of what students see and experience, things they assimilate and that become an integral part of their lives and worldview.

Therefore, if we move beyond the schoolyard to a broader perspective in terms of time and place, we see that the story of school security guards in Israel, encompasses, to some extent, changes in Israeli society over recent decades, and their liminality implies a broader sense of liminality. For, as mentioned above, In Israel, the security ethos has long been predominant (Lissak 2001; Peri 2006). It is tightly bound with mutual commitment between citizens and the state. Citizens are required and willing to sacrifice themselves to preserve the security of the nation, while the state is committed to citizens' general well-being. This reciprocal relationship was exemplified when the state's security program was based on parent-volunteers carrying out the guarding action. Today, the security ethos has been preserved in the commitment to protect all schools, but its nature has changed. Parentvolunteer guards have been replaced by private guards employed by companies who compete with each other for maximum financial gain, and their degree of commitment to their employees is low. The result is security guards who doubt are cast on their ability to properly protect the students, and whose social-economic security is undermined. In other words, there is dialectical tension between 
the collective-security ethos and the neoliberal ethos, according to which security is perceived as a commodity, and the state's commitment to the individual is reduced to a minimum. The co-existence of these two ethe creates an obscure and uncertain state of liminality arising from oscillation between two incompatible systems. Like the situation of school security guards, there is no definite time when this liminal phase will end.

\section{References}

Ali, K., Megan, B., Ayesha, D., Ifeoma, A., Adria, B., Thomas, D. R., \& Troy, D. (2013). The use of school resource officers in high schools, an analysis of practices and their applicability to Hanover, New Hampshire. The Nelson A. Rockefeller Center at Dartmouth College. https://rockefeller.dartmouth.edu/sites/rockefeller.drupalmultiprod.dartmouth.edu/files /prs_brief_1213-15.pdf

Birch, K., \& Springer, S. (2019). Peak neoliberalism? Revisiting and rethinking the concept of neoliberalism. Ephemera, 19(3), 467-485. http://ephemerajournal.org/sites/default/files/pdfs/contribution/19-3editorial_o.pdf

Beech, N. (2011). Liminality and the practices of identity reconstruction. Human Relations, 64(2), 285-302. https://doi.org/10.1177/oo18726710371235

Borg, E., \& Jonas, S. (2015). Liminality competence: An interpretative study of mobile project workers' conception of liminality at work. Management Learning, 46(3), 260-279. https://doi.org/10.1177/1350507613516247

Brenner, N., \& Theodore, N. (2002). Cities and geographies of actually existing neoliberalism. Antipode, 34(3), 349379. https://doi.org/10.1111/1467-8330.00246

Blumenthal, I. (2016, August 23). Authorities warn: School security is in a difficult state. Ynet. https://www.ynet.co.il/articles/o,7340,L-4845276,oo.html [in Hebrew]

Briken, K. (2011). Suffering in public? Doing security in times of crisis. Social Justice, 38(1-2), 128-145. https://www.jstor.org/stable/23345528?seq=1

Brown, W. (2006). American nightmare: Neoliberalism, neoconservatism, and de-democratization. Political Theory, 34(6), 690-714. https://sxpolitics.org/wp-content/uploads/2018/o5/Wendy-Brown-American-Nightmare.pdf

Caine, R. D., Burlingame, M., \& Arney, L. (1998). Off-duty police officers as school security guards in an inner-city high school: An exploratory study. The High School Journal, 82(1), 11-23. https://www.jstor.org/stable/40364706?seq=1

Daniel, M. E., \& Ellis-Chadwick, F. (2016). Entrepreneurship and liminality: The case of self-storage based businesses. International Journal of Entrepreneurial Behavior \& Research, 22(3), 436-457. https://doi.org/10.1108/IJEBR-o1-2015-0015

Davidov, G. (2010). Workers through subcontractors in schools. In O. Ichilov (Ed.), Privatization and commercialization in state education in Israel (pp. 145-73). University of Tel Aviv. [in Hebrew]

Dempsey, J. S. (2008). Introduction to private security. Belmont, CA.: Thomson Higher Education.

Devorat, Z. (2002, March 21) Security that disappoints. Globes. http://www.globes.co.il/news/article.aspx?did=572675 [in Hebrew]

Ely, M. (2010). Perceived roles and responsibilities of secondary school principals and school resource officers towards school security (Published PhD diss.). University of Tennessee. https://trace.tennessee.edu/utk_graddiss/878

Garsten, C. (1999). Betwixt and between: Temporary employees as liminal subjects in flexible organizations. Organization Studies, 2o(4), 601-617. https://doi.org/10.1177/0170840699204004

Handels, S. (2004). Security guards and watchmen in Israel 1995-2003. State of Israel, Ministry of Industry, Trade, and Labor. https://employment.molsa.gov.il/Research/Documents/shomrim.pdf

Harvey, D. (2005). A brief history of neoliberalism. Oxford: Oxford University Press.

Israel Authority for Maintaining Public Safety Law. (2005). Book of laws, Booklet 2022: 758-764. [in Hebrew]

Israel Ministry of Education. (2012a). School security practices: Principles of security, CEO circular, sec. 5.3-56. https://cms.education.gov.il/EducationCMS/Applications/Mankal/EtsMedorim/5/5-3/HoraotKeva/K-20132a-5-3-56.htm [in Hebrew]

Israel Ministry of Education. (2012b). School security practices: Principles of security, CEO circular, sec. 5.3-58. https://cms.education.gov.il/EducationCMS/Applications/Mankal/EtsMedorim/5/5-3/HoraotKeva/K-20132-1-5-3-58.htm[in Hebrew]

Israel Police. (1998). Specification 151, criteria for employees in security roles (security officers, security checker, watchman, security guard / patrol). http://www.fstyle.co.il/imgs/site/ntext2/151.pdf [in Hebrew]

James, N., \& McCallion, G. (2013). School resource officers: Law enforcement officers in schools. CRS report for Congress. https://fas.org/sgp/crs/misc/R43126.pdf 
Kahlke, R. M. (2014). Generic qualitative approaches: Pitfalls and benefits of methodological mixology. International Journal of Qualitative Methods, 13(1), 37-52. https://journals .sagepub.com/doi/pdf/10.1177/160940691401300119

Kalleberg, A. L. (2009). Precarious work, insecure workers: Employment relations in transition. American Sociological Review, 74(1), 1-22. https://onlabor.org/wp-content/uploads/2017/o1/kalleberg_Precarious_Work.pdf

Kaplan, R. (2010). Regulation. Mafteach, 1, 212-179. http://mafteakh.tau.ac.il/pdf/1-2010-o9.pdf. [in Hebrew]

Knesset. (1974). Emergency regulations (securing educational institutions). https://www.nevo .co.il/law_html/Law19/319_088.htm [in Hebrew]

Knesset Education, Culture, and Sports Committee. (2002). Protocol no. 406. http://knesset.gov.il/protocols/data/rtf/chinuch/2002-o1-30.rtf [in Hebrew]

Lansky, N. (2012, January 5). Who will Protect the Security Guards? Israel Today. https://www.israelhayom.co.il/article/36434 [in Hebrew]

Layton, D., \& Shaler, G. (2019). School-based policing in Maine: A study on school resource officers in Maine's public schools. Maine Statistical Analysis Center, 3. https://digitalcommons.usm.maine.edu/maine_statistical analysis_center/3/

Levy, S. (2005). Characteristics of employment of security and security workers in Israel: Background document. Knesset Research and Information Center. https://fs.knesset.gov.il/globaldocs/MMM/1o6cced5-8e32-e811-8odeoo155doao235/2_106cced5-8e32-e811-8ode-oo155doao235_11_6883.pdf [in Hebrew]

Lincoln, Y. S., \& Guba, E. (1985). Naturalistic inquiry. Newbury Park, CA.: Sage.

Lissak, M. (2001). The ethos of security and the myth of the militarized society. In S. A. Cohen (Ed.), Democratic culture 4-5 (pp. 187-211). Ramat Gan: Bar-Ilan University. [in Hebrew]

Maskaly, J., Donner, M. C., Lanterman, J., \& Jennings, G. W. (2011). On the association between SROs, private security guards, use-of-force capabilities, and violent crime in schools. Journal of Police Crisis Negotiations, 11, 159-176. https://www.tandfonline.com/doi/abs/10.108o/15332586.2011.587381

Mandelkern, R. (2015). Postscript to the Hebrew edition: A brief history of neoliberalism in Israel. In D. Harvey (author), A brief history of neoliberalism (G. Harlling, Trans.) (pp. 271-312). Jerusalem: Molad. [in Hebrew]

Manzo, J. (2006). "You can't rent a cop": Mall security officers' management of a "stigmatized" occupation. Security Journal, 19(3), 196-210. https://doi.org/10.1057/palgrave.sj.8350018

Manzo, J. (2011). On the practices of private security officers: Canadian security officers' reflections on training and legitimacy. Social Justice, 38(1-2), 107-126. http://www.socialjusticejournal.org/product/john-manzo/

Merriam, S. B. (2002). Introduction to qualitative research. In S. B. Merriam (Ed.), Qualitative research in practice: Examples for discussion and analysis (pp. 1-17). San Francisco, CA.: Jossey-Bass.

Merriam, S. B., \& Tisdell, E. J. (2016). Qualitative research: A guide to design and implementation (4th ed.). San Francisco, CA.: Jossey-Bass.

Meško, G., Nalla, M., \& Sotlar. A. (2005). Cooperation of police and private security officers in crime prevention in Slovenia. In E. Marks, A. Meyer \& R. Linssen (Eds.), Quality in crime prevention (pp. 133-143). Norderstedt: Books on Demand GmbH.

Municipality of Haifa. (2018). Security in educational institutions, inspection report. http://tiny.cc/tkqaoz [in Hebrew]

Nalla, M., \& Cobbina, J. (2017). Environmental factors and job satisfaction: The case of private security guards. Security Journal, 30, 215-226. https://doi.org/10.1057/sj.2016.12

Noronha, E., Chakraborty, S., \& D'Cruz. P. (2020). "Doing dignity work": Indian security guards' interface with precariousness. Journal of Business Ethics, 162, 553-575. https://doi.org/10.1007/s10551-018-3996-x

Nissim, G., \& De Vries, D. (2014). Permanent liminality: The impact of non-standard forms of employment on workers' committees in Israel. International Labour Review, 153(3), 435-454. https://doi.org/10.1111/j.1564913X.2014.00010.X

Palys, T. (2008). Purposive sampling. In: L M. Given (Ed.), The Sage encyclopedia of qualitative research methods (vol.2.) (pp. 697-698). Los Angeles: Sage.

Patton, M. Q. (1999). Enhancing the quality and credibility of qualitative analysis. HSR: Health Services Research, 34(5 pt. 2) 1189-1208. https://www.ncbi.nlm.nih.gov/pmc/articles/PMC1089059/pdf/hsresearchooo22-o112.pdf

Patton, M. Q. (2002). Qualitative research and evaluation methods (3rd ed.). London: Sage.

Peri, Y. (2006). Generals in the cabinet room: How the military shapes Israeli policy. Washington, DC.: Institute of Peace Press.

Prenzler, T. (2004). The privatization of policing. In R. Sarre \& J. Tomaino (Eds.), Key issues in criminal justice (pp. 267-296). Unley: Australian Humanities Press.

Schlesinger, L. (2013, March 2). Investigation: Why do security guards leave work with weapons? NRG. http://www.nrg.co.il/online/1/ART2/446/853.html_[In Hebrew] 
Shukla, M. S. (2017). Security management: A comprehensive guide for improving security environment. Chennai: Notion Press.

Spyridakis, M. (2013). The liminal worker: An ethnography of work, unemployment and precariousness in contemporary Greece. Farnham and Burlington: Ashgate..

Strauss, A., \& Corbin, J. (1998). Basics of qualitative research: Techniques and procedures for developing grounded theory (and ed.). London: Sage.

Szakolczai, A. (2003). Reflexive historical sociology. London: Routledge.

Tagliaventi, R. M. (2020). Liminality in organization studies: Theory and method. New York: Routledge.

Thomassen, B. (2009). The uses and meanings of liminality. International Political Anthropology, $2(1), 5-27$. http://www.politicalanthropology.org/

Thorsen, D. E., \& Lie, A. (2007). What Is neoliberalism? University of Oslo: 2-17. http://folk.uio.no/daget/neoliberalism2.pdf

Turner, V. W. (1967). The forest of symbols: Aspects of Ndembu ritual. Ithaca, NY.: Cornell University Press.

Turner, V. W. (1969). The ritual process: Structure and anti-structure. Chicago, IL.: Aldine.

Turner, V. W. (1988). The anthropology of performance. New York: PAJ.

Underthun, A., \& Jordhus-Lier, D. C. (2018). Liminality at work in Norwegian hotel. Tourism Geographies, 2o(1), 11- 28. https://doi.org/10.108o/14616688.2017.1314546

Van Gennep, A. (1960). The rites of passage. Chicago, IL: University of Chicago Press.

Van Steden, R., \& Nalla, M. K. (2010). Citizen satisfaction with private security guards in the Netherlands: Perceptions of an ambiguous occupation. European Journal of Criminology, 7(3), $214-234$. https://doi.org/10.1177/1477370809359264

Van Steden, R., \& Sarre, R. (2010). The tragic quality of contract guards: A discussion of the reach and theory of private security in the world today. The Journal of Criminal Justice Research, 1(1), 1-19. https://www.academia.edu/3421788/The_tragic_quality_of_contract_guards_a_discussion_of_the_reach_an d_theory_of_private_security_in_the_world_today

Wininger, A., \& Teschner, N. (2013). Oversight of the employment conditions of security workers in educational institutions in the local authorities. Knesset Research and Information Center. http://dinonline.info/pdf/kn93.pdf [in Hebrew]

Winkler, I., \& Mahmood, M. K. (2015). The liminality of temporary agency work: Exploring the dimensions of Danish temporary agency workers' liminal experience. Nordic Journal of Working Life Studies, 5(1), 51-68. https://doi.org/10.19154/njwls.v5i1.4765

Zedner, L. (2006). Liquid security: Managing the market for crime control. Criminology and Criminal Justice, 6(3), 267-288. https://doi.org/10.1177/1748895806065530

Zvi Cohen, N. (2018, August 9). Guarding the continuum. Davar, Workers, Society and Economy in Israel. https://www.davar1.co.il/142922/ [in Hebrew] 